\title{
Retraction Note: Stress urinary incontinence: long-term results of laparoscopic Burch colposuspension
}

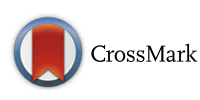

Domenico Prezioso ${ }^{1}$, Fabrizio lacono ${ }^{1}$, Giovanni Di Lauro ${ }^{2}$, Ester Illiano ${ }^{1 *}$, Giuseppe Romeo ${ }^{1}$, Antonio Ruffo ${ }^{1}$, Nicola Russo ${ }^{1}$ and Bruno Amato $^{3}$

\section{Retraction Notice}

This article [1] has been retracted by the authors because it contains large portions of text that were duplicated from a number of pervious publications including Rofeim et al. [2], Carey et al. [3] and Hong et al. [4]. The authors apologise for failing to cite these articles.

\section{Notes}

The online version of the original article can be found at 10.1186/1471-2482-13-S2-S38.

\footnotetext{
Author details

'Department of Urology, University Federico II of Naples, Via S. Pansini, 5, Naples 80131, ITALY. ${ }^{2}$ Hospital Santa Maria delle Grazie, Pozzuoli, Naples Via Domiziana, Loc. La Schiana, Pozzuoli, Naples, Italy. ${ }^{3}$ Department of General, Geriatric, Oncologic Surgery and Advanced Technologies, University

"Federico II" of Naples, Via Pansini, 5, Naples 80131, Italy.
}

Received: 10 March 2016 Accepted: 30 March 2016

Published online: 28 April 2016

\section{References}

1. Prezioso D, lacono F, Lauro G, lliano E, Romeo G, Ruffo A, Russo N, Amato B. Stress urinary incontinence: long-term results of laparoscopic Burch colposuspension. BMC Surg. 2013;13 Suppl 2:S38. doi:10.1186/1471-2482-13S2-S38.

2. Rofeim $O$, Yohannes $P$, Badlani G. Minimally invasive procedures for urethral incontinence: is there a role for laparoscopy? Int Braz J Urol. 2002;28:403-12.

3. Carey M, Goh J, Rosamilia A, Cornish A, Gordon I, Hawthorne G, Maher CF, Dwyer PL, Moran P, Gilmour DT. Laparoscopic versus open Burch colposuspension: a randomised controlled trial. BJOG. 2006;113:999-1006.

4. Hong JH, Choo MS, Lee KS. Long-term results of laparoscopic Burch colposuspension for stress urinary incontinence in women. J Korean Med Sci. 2009;24(6):1182-6.

\footnotetext{
* Correspondence: ester.illiano@inwind.it

'Department of Urology, University Federico II of Naples, Via S. Pansini, 5, Naples 80131, ITALY
}

Full list of author information is available at the end of the article

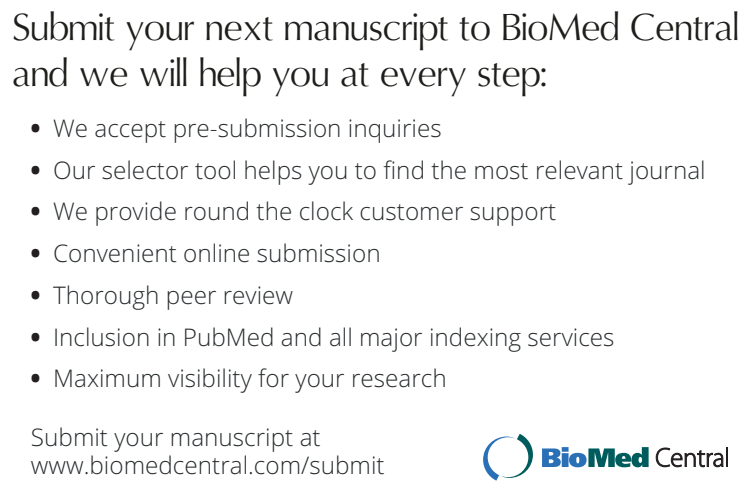

- We accept pre-submission inquiries

- Our selector tool helps you to find the most relevant journal

- We provide round the clock customer support

- Convenient online submission

- Thorough peer review

- Inclusion in PubMed and all major indexing services

- Maximum visibility for your research

Submit your manuscript at www.biomedcentral.com/submit

\section{C) Biomed Central}

(C) 2016 Prezioso et al. Open Access This article is distributed under the terms of the Creative Commons Attribution 4.0 International License (http://creativecommons.org/licenses/by/4.0/), which permits unrestricted use, distribution, and reproduction in any medium, provided you give appropriate credit to the original author(s) and the source, provide a link to the Creative Commons license, and indicate if changes were made. The Creative Commons Public Domain Dedication waiver (http://creativecommons.org/publicdomain/zero/1.0/) applies to the data made available in this article, unless otherwise stated. 